\title{
Adaptation of energy metabolism to undernutrition in ewes. Contribution of portal-drained viscera, liver and hindquarters
}

\author{
BY ISABELLE ORTIGUES AND D. DURAND \\ Laboratoire Croissance et Métabolismes des Herbivores, INRA, Theix, 63122 Saint Genès \\ Champanelle, France
}

(Received 9 December 1993 - Revised 16 May 1994 - Accepted 14 June 1994)

\begin{abstract}
Adaptation of energy metabolism to undernutrition and to the duration of undernutrition was studied in adult, non-pregnant, non-lactating ewes at the whole-animal, portal-drained viscera, liver and hindquarters levels. Arterio-venous and indirect calorimetry techniques were used. Animals were successively fed at 1 times ( 3 weeks) and at 0.5 times ( 7 weeks) their metabolizable energy requirements for maintenance (MEm). Portal, hepatic and hindquarters blood flows in quietly standing ewes decreased by 22,19 and $11 \%$ respectively within the first week of undernutrition and remained at that level thereafter. Standardizing hindquarters blood flow to that in a given posture (quietly standing) reduced blood flow by $9.8 \%$. In the portal-drained viscera and liver, $\mathrm{O}_{2}$ extraction rates decreased, leading to 34 and $38 \%$ drops in $\mathrm{O}_{2}$ consumption with underfeeding respectively. In the hindquarters, $\mathrm{O}_{2}$ extraction rate increased, partly counterbalancing the drop in blood flow. Thus $\mathrm{O}_{2}$ consumption of hindquarters tended to decrease but the effect was not significant. All changes appeared to be completed from day 5 of underfeeding. Consequently, the portal-drained viscera, liver and carcass were responsible for 39,32 and $5 \%$ respectively of the drop in whole-animal $\mathrm{O}_{2}$ consumption with underfeeding. At the end of the $0.5 \times \mathrm{MEm}$ period, in vivo metabolic rates averaged $1.65,4.89$ and $0.38 \mathrm{mmol} \mathrm{O}_{2}$ consumed/d per $\mathrm{g}$ fresh weight of adipose-tissue-free portal-drained viscera, liver and boneless hindquarters respectively. Undernutrition imposed a much greater nutritional challenge to splanchnic tissues than to hindquarters. The former reduced their energy expenditure whereas hindquarters metabolism adapted by counteracting the slight drop in nutrient supply.
\end{abstract}

Energy metabolism: Hindquarters: Liver: Undernutrition: Viscera

Energy utilization by tissues of economic importance (e.g. muscles, mammary gland) depends partly on the partition of metabolizable energy (ME) supply among all body-tissue compartments. Feeding level may modify this partition. Changes in the plane of feeding are associated with changes in energy expenditure of splanchnic tissues (Huntington, 1990). Since the latter contribute to a substantial proportion of whole-animal energy expenditure (35-50\%; Huntington, 1990), it can be questioned whether a small modification in their energy requirements might modify the partition of energy to the benefit of peripheral tissues. The effects of feeding level have mostly been studied with animals fed at levels above maintenance. It was of particular interest to test whether in a context of undernutrition the drop in energy expenditure of splanchnic tissues could be an adaptive mechanism that would contribute to muscle saving.

The time-scale of the adaptation process is also important. The lag time for changes in whole-animal energy expenditure following feed restriction was shown to vary between 6 and $21 \mathrm{~d}$ (Clapperton \& Blaxter, 1965; Wainman et al. 1972). By contrast, Shetty (1990) suggested, in a critical literature review on human starvation, that responses at tissue level would take place over a longer period of time and in two stages. A short-term (2-3 weeks) response would consist of a decreased metabolic activity of body tissues, whereas a long- 
term response would correspond to the loss of mass of metabolically active tissues. Most in vivo studies on the effects of feeding level on splanchnic energy metabolism in ruminants have been conducted at set times after a few weeks of adaptation to feed allowances. Only one study, by Burrin et al. (1989), tackled the time trend effect in lambs; however there was some confounding between time trend and changes in feed intake.

As far as muscle is concerned, there is unclear evidence as to whether muscle metabolic activity would decrease substantially with underfeeding (Lobley, 1990) thus constituting another mechanism for energy saving. Muscle metabolism is known to adapt to undernutrition (Henriksson, 1992). It can thus be questioned whether quantitative changes would be sufficiently large, after a relatively long adaptation period, to be detected.

In this context, the first objective of the present paper was to study the progressive changes in in vivo energy expenditure of the portal-drained viscera (PDV), liver and hindquarters in adult, non-pregnant, non-lactating ewes submitted to a feed restriction for a relatively long period ( 7 weeks). The second objective was to measure the changes in the contribution of tissues to whole-animal energy metabolism after 7 weeks of underfeeding.

\section{MATERIALS AND METHODS}

Animals and housing

Six adult, non-pregnant, non-lactating Limousin $\times$ Romanov ewes were used. They were 5.8 (SE 0.95 ) years old, had a shorn live weight (LW) of 50.2 (SE 1.25 ) $\mathrm{kg}$ and had a body condition score of 3/5. After a 3-week adaptation period to the facilities, diets and handling procedures, animals were surgically fitted with chronic indwelling catheters in the portal vein (PV), a hepatic vein (HV), a mesenteric vein, a ruminal vein, the caudal vena cava (VC) and a mesenteric artery (MA) as described by Ortigues et al. (1994). An ultrasonic flow probe was also implanted around the caudal aorta (Ao) in between the renal and the iliac arteries.

Animals were left to recover from surgery for approximately $10 \mathrm{~d}$ during which they resumed their normal eating habits. Subsequently, they were housed on a slatted floor in individual cages equipped with automatic feeders. Constant lighting was applied and room temperature was maintained at $18^{\circ}$.

\section{Diet and feeding}

The diet was composed of orchard-grass (Dactylis glomerata) hay only, with a ME content initially estimated (Institut National de la Recherche Agronomique, 1978) at 8.79 MJ/kg dry matter (DM). A commercial macromineral supplement (Ovitonic; Saunders, 91200 Athis Mons, France) was distributed daily and a mineral block (Oligobloc; Compagnie des Salins du Midi et des Salins de l'Est, 34063 Montpellier, France) was always available in order to cover the maintenance requirements for minerals and trace elements (Underwood, 1981).

Following the recovery period, animals were fed for 3 weeks (weeks -3 to -1 or days -21 to -1 ) at maintenance $\left(335 \mathrm{~kJ} \mathrm{ME} / \mathrm{kg} \mathrm{LW}^{0.75}\right.$ (metabolic live weight, $\mathrm{MW}$ ), for indoors and individually caged ewes (M. Vermorel, personal communication)) calculated on the basis of initial LW. Feed allowances were then abruptly decreased by half and remained at that level for $7 \cdot 5$ weeks (weeks +1 to +7 or days +1 to +52 ). Animals were fed continuously at intervals of $3 \mathrm{~h}$ (eight equal daily meals) and had ad lib. access to water.

\section{Measurements}

Feeds. Hay DM content was measured daily in a draught air oven $\left(80^{\circ}\right.$ for $24 \mathrm{~h}$ ). Representative feed samples were taken for each period (maintenance and half 
maintenance) and each animal, and ground through a $1 \mathrm{~mm}$ screen awaiting chemical analysis for ash, $\mathrm{N}$ and gross energy (GE).

Sampling protocol. Weekly measurements at tissue level were conducted on each animal during the last 2 weeks of the maintenance period (days -9 and -5 ) and the 7 weeks of the half-maintenance period (days $+5,+10,+17,+24,+31,+38$ and +45 ). Each measurement series was carried out over two feeding cycles (i.e. $6 \mathrm{~h}$ ), during which the animals were tied by the neck close to the trough.

Blood flow through the hindquarters was measured ultrasonically (Transonic Systems Inc., Ithaca, NY, USA). Instantaneous measures (1770 scrutations) were integrated over each minute and recorded on a microcomputer. In addition, and in order to improve the interpretation of hindquarters blood-flow data, animal behaviour (lying, standing, moving, eating) was recorded manually.

Splanchnic blood-flow rates were obtained using the dilution technique described by Ortigues et al. (1994). p-Aminohippuric acid (PAH) was infused continuously and simultaneously via both the mesenteric and the ruminal veins $(0.2 \mathrm{mg} \mathrm{PAH} / \mathrm{min}$ per $\mathrm{kg} \mathrm{LW}$ in total) after a prime injection $(3.75 \mathrm{mg} \mathrm{PAH} / \mathrm{kg} \mathrm{LW})$. Infusion started $45 \mathrm{~min}$ before sampling.

A total of twelve blood samples was taken from each of the major blood vessels (PV, HV, VC, MA) over the $6 \mathrm{~h}$ period. Sampling started $15 \mathrm{~min}$ after a meal and was repeated at intervals of $30 \mathrm{~min}$. To ensure uniformity in sample collection, all samples were taken while the ewes were standing quietly (at least $4 \mathrm{~min}$ after they had stood up if they were previously lying down). Ewes were allowed to lie down between samples. Each sample consisted of two $3 \mathrm{ml}$ portions of whole blood. The first $3 \mathrm{ml}$ portion was withdrawn anaerobically using a heparinized glass syringe. Syringes were stoppered with a septum in order to avoid any air contamination in the sample and stored on ice for a maximum of $30 \mathrm{~min}$, awaiting $\mathrm{O}_{2}$ analysis. Preliminary tests showed that some gas losses took place during the sampling procedure $(-7.28$ (SE 0.308$) \%, n=10)$ but that syringes could be stored for $60 \mathrm{~min}$ without any further changes in gas concentrations. The same blood samples were subsequently used for packed cell volume and PAH determinations. The second $3 \mathrm{ml}$ portion of each blood sample was collected gravimetrically into a test tube and used for metabolite analyses (results not shown).

Live weight and body composition. Animals were weighed twice weekly. At the end of the experiment animals were slaughtered (day +52 ) and dissected. Blood was weighed. Internal organs and adipose tissues (oesophagus, reticulo-rumen, omasum, abomasum, small intestine, colon, caecum, pancreas, spleen, bile, abdominal fat, liver) were removed, weighed separately (with and without digestive contents when relevant, as well as after trimming of visible adipose tissues) and sampled for DM. Stomachs and intestines were then pooled, minced and stored at $-15^{\circ}$ for chemical analysis (N, GE). Abdominal fat and liver were minced separately and stored before analysis ( $\mathbf{N}$ for liver only, GE). The carcass was separated between the first and second lumbar vertebrae (corresponding to the location of the vena cava catheter tip) and both the hindquarters and the remainder (forequarters) were dissected into skin, bones and meat, and weighed. DM was determined on skin and meat. Samples of skin and meat were then minced and stored at $-15^{\circ}$ for chemical analysis (N, GE).

Respiratory exchanges and time spent standing. $\mathrm{O}_{2}$ consumption, $\mathrm{CO}_{2}$ and $\mathrm{CH}_{4}$ production were measured in respiration chambers (Vermorel et al. 1973) on two consecutive days at the end of the maintenance (days -2 and -1 ) and half-maintenance (days +47 and +48 ) feeding periods, after a $1 \mathrm{~d}$ adaptation to the chambers. Outlet air flow was measured every $5 \mathrm{~min}$ and average daily $\mathrm{O}_{2}, \mathrm{CO}_{2}$ and $\mathrm{CH}_{4}$ concentration differences between inlet and outlet air were measured on a $24 \mathrm{~h}$ composited outlet air 
sample. While in the respiration chambers the animals were equipped with a harness connected to a contacter that enabled the recording of posture (standing or lying) every $5 \mathrm{~min}$.

\section{Chemical analyses}

Total $\mathrm{O}_{2}$ concentrations in whole blood were measured polarographically (Radiometer electrode E5046/0, Copenhagen, Denmark) after disrupting the erythrocytes present in the sample and displacing the $\mathrm{O}_{2}$ associated with haemoglobin using a saponin $(3 \mathrm{~g} / \mathrm{l})-$ potassium ferricyanide $(6 \mathrm{~g} / 1)$ solution (Tucker, 1967).

PAH was analysed by spectrophotometry according to the method described by Huntington (1982) which does not include a hydrolysis step to allow for acetylation in hepatic blood. Packed cell volume was obtained by centrifuging whole blood in capillary tubes.

DM of feeds and tissues was determined at $80^{\circ}$ for $48 \mathrm{~h}$ and ash at $550^{\circ}$ for $6 \mathrm{~h}$. $\mathrm{N}$ was total Kjeldahl $\mathrm{N}$ and $\mathrm{GE}$ was measured using an adiabatic bomb calorimeter.

\section{Calculations}

Splanchnic blood flows were calculated as described by Katz \& Bergman (1969):

$$
\begin{aligned}
& B F_{p v}=\frac{I}{C_{p v}-C_{m a}}, \\
& B F_{h v}=\frac{I}{C_{h v}-C_{m s}},
\end{aligned}
$$

where $\mathrm{BF}_{\mathrm{pv}}$ and $\mathrm{BF}_{\mathrm{hv}}$ are portal and hepatic blood flows (litres/min) respectively, $\mathrm{I}$ is $\mathrm{PAH}$ infusion rate $(\mathrm{g} / \mathrm{min})$ and $\mathrm{C}_{\mathrm{pv}}, \mathrm{C}_{\mathrm{hv}}$ and $\mathrm{C}_{\mathrm{ma}}$ are $\mathrm{PAH}$ concentrations in portal, hepatic and arterial blood $(\mathrm{g} / \mathrm{l})$ respectively.

The twelve instantaneous blood flow results obtained for each day of measurement were corrected, if necessary, as described by Ortigues et al. (1994). If the coefficient of variation (CV) calculated from the twelve results was greater than a reference $\mathrm{CV}(11 \%)$, a maximum of two values was eliminated in order to bring the CV down close to $11 \%$. The reference CV had been determined when infusing PAH via both a mesenteric and a ruminal vein. After corrections, average daily portal and hepatic blood flows were calculated, and daily hepatic arterial blood flows $\left(\mathrm{BF}_{\mathrm{ha}}\right)$ were obtained by difference between average $\mathrm{BF}_{\mathrm{pv}}$ and $\mathrm{BF}_{\mathrm{hv}}$.

Observed blood flows measured in Ao were first analysed in order to remove any variations due to changes in posture or physical activity. Corrections were applied as described by Isserty \& Ortigues (1994) so that corrected blood flows would be representative of a quietly standing animal. Briefly, blood flows measured during lying or agitation phases were eliminated. A unilateral confidence interval $(P<0.05)$ was subsequently calculated on the remaining results and any value greater than the upper limit of the confidence interval was eliminated assuming it would be representative of periods of intermediate activity. The majority of results eliminated using this procedure corresponded to blood flows measured when the experimenter entered or left the pen around sampling times (Isserty \& Ortigues, 1994). Remaining values were used to calculate the average daily blood flow in $\mathrm{Ao}\left(\mathrm{BF}_{\mathrm{Ao}}\right)$.

Splanchnic and hindquarters $\mathrm{O}_{2}$ fluxes were calculated as the products of blood flows and the corresponding gas concentrations.

$\mathrm{O}_{2}$ consumption rates ( $\left.\mathrm{mmol} / \mathrm{min}\right)$ by PDV $\left(\mathrm{V}_{\mathrm{O2}, \mathrm{PDV}}\right)$, liver $\left(\mathrm{V}_{\mathrm{O2,L}}\right)$ and hindquarters $\left(\mathrm{V}_{\mathrm{O} 2, \mathrm{HQ}}\right)$ were calculated using the following equations: 


$$
\begin{aligned}
\mathrm{V}_{\mathrm{O}, \mathrm{PDV}} & =B F_{\mathrm{pv}} \times\left(\mathrm{O} 2_{\mathrm{ma}}-\mathrm{O} 2_{\mathrm{pv}}\right), \\
\mathrm{V}_{\mathrm{O}, \mathrm{L}} & =\left(B F_{\mathrm{pv}} \times \mathrm{O} 2_{\mathrm{pv}}\right)+\left(B F_{\mathrm{hQ}} \times \mathrm{O} 2_{\mathrm{mQ}}\right)-\left(B F_{\mathrm{hv}} \times \mathrm{O} 2_{\mathrm{hv}}\right), \\
\mathrm{V}_{\mathrm{O}, \mathrm{HQ}} & =B F_{\mathrm{AO}} \times\left(\mathrm{O} 2_{\mathrm{ma}}-\mathrm{O} 2_{\mathrm{vc}}\right)
\end{aligned}
$$

where $\mathrm{O} 2_{\mathrm{ma}}, \mathrm{O} 2_{\mathrm{pv}}, \mathrm{O} 2_{\mathrm{hv}}$ and $\mathrm{O} 2_{\mathrm{vc}}$ are the $\mathrm{O}_{2}$ concentrations in arterial, portal, hepatic and vena cava blood ( $\mathrm{mmol} / \mathrm{l})$ respectively.

$\mathrm{O}_{2}$ extraction rates by tissue beds were obtained as the ratio between $\mathrm{O}_{2}$ consumption rate and $\mathrm{O}_{2}$ supply to the tissue.

\section{Statistical analyses}

Results obtained between weeks -2 and +5 were analysed according to the univariate repeated-measures analysis (Statistical Analysis Systems, 1987) using 'week' as the repeated-measures factor. The Huynh \& Feldt epsilon (HF Eps) adjustment factor of the $F$ test was used to account for unequal correlations between repeated measures (Homer, 1989). This factor is reported in addition to the standard error of treatment means (SEM = $\checkmark$ (residual mean squares/number of observations per treatment)). Means were compared by orthogonal contrasts.

Because of missing data in weeks +6 and +7 , available results were analysed by paired $t$ test.

\section{RESULTS}

\section{Feed composition and intake}

The chemical composition of the hay offered averaged $929 \mathrm{~g}$ organic matter (OM), 18.63 MJ GE and $17.62 \mathrm{~g}$ total N/kg DM. Metabolizability of the hay averaged 0.42 (I. Ortigues and M. Vermorel, unpublished results). Daily intakes averaged 745 (SE 32.2) g DM, 693 (SE 29.9) g OM, 6.12 (SE 0.263) MJ ME and 13.30 (SE 0.637) g N at maintenance. They decreased significantly with underfeeding and remained relatively stable over the whole half-maintenance period at 385 (SE 5.4) g DM, 357 (SE 5.2) g OM, 2.94 (SE 0.041) MJ ME and 6.76 (SE 0-104) g N at half maintenance.

\section{Animals and blood catheters}

Ewes had an initial LW of 50.2 (SE 1.25 ) $\mathrm{kg}$ on day -21 . They lost 79 (SE 24.8 ) g/d over the maintenance period. Reducing intake by half induced a weight loss of 1.9 (sE 0.37) kg within the first $3 \mathrm{~d}$ and of 116 (SE 4.3) $\mathrm{g} / \mathrm{d}$ subsequently. Animals did not appear to suffer from the intense blood sampling schedule. It was checked that packed cell volume remained stable throughout the experiment at an average of $0 \cdot 21$.

In one animal the HV catheter was misplaced so results involving measurements at the HV level were obtained in five ewes only. In three out of the six ewes the ruminal vein catheters became rapidly non-functional. In these cases PAH infusions were carried out via the mesenteric vein only. From week +6 onwards other catheters started to malfunction and recording of $\mathbf{B F}_{\mathbf{A o}}$ was impaired due to technical mishaps on a few animals. Consequently, complete results for tissue energy metabolism were available for weeks -2 to +5 only. The exact numbers of observations for each data point are reported in the relevant tables. Results obtained for weeks +6 and +7 are mentioned in the text but no data are reported. Another consequence of these difficulties was that respiratory exchange measurements and slaughter were carried out 1 week ahead of schedule for two animals. 


\section{Blood flows}

Portal blood flow averaged $2 \cdot 36$ litres/min at maintenance. It dropped by $22 \%$ from day +5 onwards $(P<0.0001)$ and maintained itself at an average of 1.87 litres $/ \mathrm{min}$ over the first 5 weeks of the half-maintenance period (Table 1). No further changes were noted in weeks +6 and +7 . Similarly, hepatic blood flow decreased from $2.62 \mathrm{litres} / \mathrm{min}$ at maintenance to 2.11 litres $/ \mathrm{min}$ at half-maintenance $(P<0.001)$. Intermediate blood-flow values were measured on day +5 but they were due to two animals only and the effect was not significant. The changes in hepatic venous blood flow with underfeeding $(-0.51$ litres/min on average) were primarily due to changes in portal blood flow $(-0.49$ litres $/ \mathrm{min}$ ). Indeed, blood flow in the hepatic artery tended to decrease with underfeeding, however the effect was not significant and the contribution of $\mathrm{BF}_{\mathrm{ha}}$ to $\mathrm{BF}_{\mathrm{hv}}$ remained stable at about $12.5 \%$ throughout the whole experiment. The low hepatic artery blood flow noted in week +1 was due to two animals only. No further changes in portal, venous and arterial hepatic blood flows were noted in weeks +6 and +7 (results not shown).

Positive and significant correlations were calculated between portal or hepatic blood flows and ME intake (MEI) using results obtained for weeks $-2,-1,+4$ and +5 . However, at a given MEI (half maintenance) blood flows did not appear to be correlated with $\mathrm{LW}$ nor with time on feed.

Observed Ao blood flows averaged 0.54 litres/min at maintenance and decreased to an average of 0.50 litres $/ \mathrm{min}$ in the first 5 weeks of underfeeding $(P<0.05$; Table 1$)$. This effect was noted from the comparison of blood flows obtained between week -2 and weeks +1 to +5 only, since some variability existed during the maintenance period. No significant differences were noted during the half-maintenance period up to week +7 (results not shown). Corrected Ao blood flows, corresponding to quietly standing ewes, were on average $9.8 \%$ lower than observed flows. The effects of undernutrition were similar in both cases except that the level of significance was higher with the corrected $\mathrm{BF}_{\mathrm{A} 0}($ Table 1). Positive but non-significant correlations were noted between corrected Ao blood flows and MEI, when results obtained for weeks $-2,-1,+4$ and +5 were used. Similarly, corrected Ao blood flows, measured during the underfeeding period, were not significantly correlated with LW nor with time on feed.

\section{Oxygen consumption by tissues}

Whole-blood arterial $\mathrm{O}_{2}$ concentrations were not affected by undernutrition (Table 2). Splanchnic arterio-venous (A-V) concentration differences decreased significantly at the onset of underfeeding. However, throughout the underfeeding period, portal A-V differences remained stable whereas hepatic $A-V$ differences showed intermediate values in week $+1(P<0.05)$. These effects were associated with lower $\mathrm{O}_{2}$ extraction rates by the PDV $(0.22$ v. 0.26 on average, $P<0.10)$ and the liver $(0.19 v .0 .25$, not significant) during the half-maintenance period. No further changes were observed in weeks +6 and +7 of underfeeding (results not shown).

In the hindquarters, $\mathrm{A}-\mathrm{V} \mathrm{O}$ concentration differences and subsequently $\mathrm{O}_{2}$ extraction rates were not or only slightly significantly $(P<0 \cdot 10)$ increased by underfeeding from week +3 onwards, and remained elevated until week +7 (Table 2 ). It should be noted that the $\mathrm{O}_{2}$ extraction rates in the hindquarters $(0.61)$ were on average $2.6-2.9$ times as high as those in the PDV $(0 \cdot 23)$ or liver $(0 \cdot 21)$.

Consequently, $\mathrm{O}_{2}$ supply to the PDV and liver decreased significantly from day 5 of undernutrition onwards by $21 \%$ (from 11.57 to $9.16 \mathrm{mmol} / \mathrm{min}, P<0.001$ ) and by $18 \%$ (from 9.71 to $7.97 \mathrm{mmol} / \mathrm{min}, P<0.02$ ) respectively. $\mathrm{O}_{2}$ consumption by the $\mathrm{PDV}$ decreased by $34 \%$ (from $2.95 \mathrm{mmol} / \mathrm{min}$ on average at maintenance to 1.93 at half- 
ADAPTATION TO UNDERNUTRITION

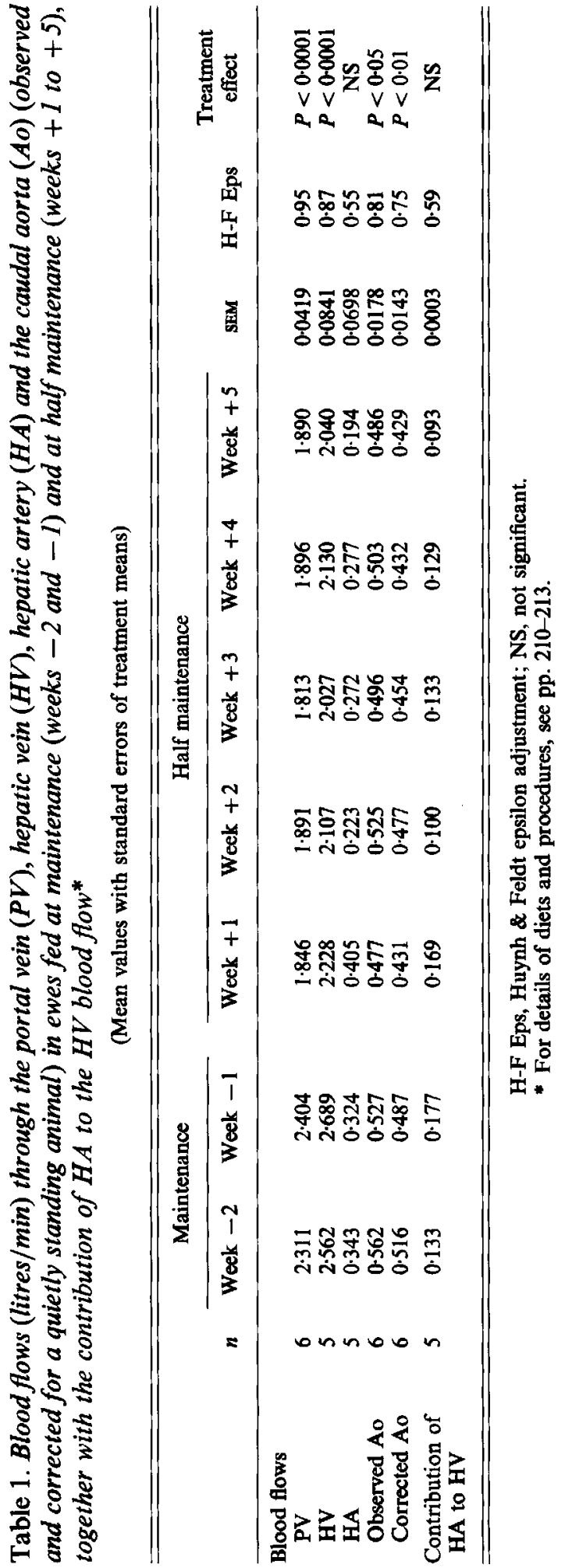


I. ORTIGUES AND D. DURAND

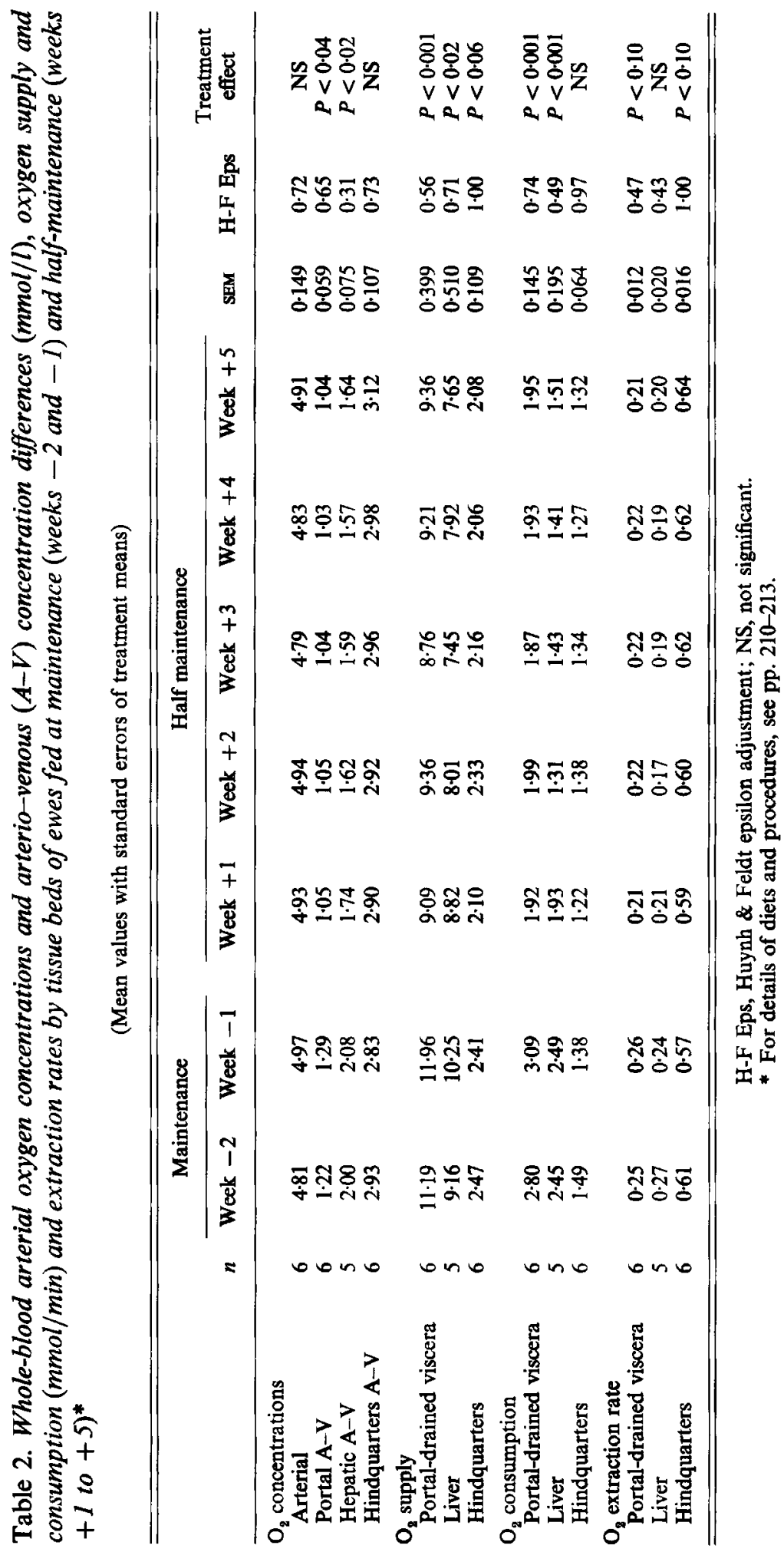


maintenance, $P<0.001$ ) with underfeeding. This change occurred very rapidly within the first $5 \mathrm{~d}$ of underfeeding and $\mathrm{O}_{2}$ consumption by the PDV remained stable until the 7 th week of underfeeding (Table 2). Similarly, $\mathrm{O}_{2}$ consumption by the liver decreased by $38 \%$ (from 2.47 to $1.52 \mathrm{mmol} / \mathrm{min}, P<0.001$ ) with underfeeding. The drop in hepatic $\mathrm{O}_{2}$ consumption appeared to occur slightly more progressively than that in the PDV. Indeed, an intermediate value was measured in week +1 even if this effect was not significant because of a high animal variability noted in that week. Hepatic $\mathrm{O}_{2}$ consumption then remained stable between weeks +2 to +7 (Table 2 ).

In the hindquarters $\mathrm{O}_{2}$ supply was lowered by $12 \%$ only (from 2.44 to $2.15 \mathrm{mmol} / \mathrm{min}$, $P<0.06) . \mathrm{O}_{2}$ consumption was not significantly affected by 7 weeks of underfeeding even though it tended to decrease from $1.44 \mathrm{mmol} / \mathrm{min}$ at maintenance to $1.31 \mathrm{mmol} / \mathrm{min}$ at half maintenance (Table 2).

\section{Whole-animal respiratory exchanges}

Respiratory exchanges of ewes were measured during the last week at maintenance and on week +6 or +7 of undernutrition depending on the time blood catheters became nonfunctional. However, results obtained in weeks +6 and +7 were expressed on a MW basis and pooled since a parallel experiment showed that energy expenditure of ewes remained unchanged over the whole underfeeding period when expressed on a MW basis (I. Ortigues and $\mathbf{M}$. Vermorel, unpublished results).

Average $\mathrm{O}_{2}$ consumption amounted to 17.7 (SE 0.60) and 13.7 (SE 0.72) litres/kg MW per $d$ at maintenance and half maintenance respectively. $\mathrm{CO}_{2}$ and $\mathrm{CH}_{4}$ production averaged 17.8 (SE 0.74) and 1.27 (SE 0.076) litres/ $\mathrm{kg} \mathrm{MW}$ per d at maintenance and 13.1 (SE 0.63) and 0.80 (SE 0.038) litres $/ \mathrm{kg} \mathrm{MW}$ per d at half maintenance respectively. Consequently, energy expenditure averaged 368 (SE 13.3) and 284 (SE 12.8) kJ/kg MW per d. Respiratory quotients averaged 1.01 (SE 0.018 ) and 0.96 (SE 0.009) respectively.

Absolute values of $\mathrm{O}_{2}$ consumption by catheterized ewes over the first weeks of undernutrition were predicted in order to calculate the contributions of tissues to these variables. The parallel experiment mentioned above (I. Ortigues and M. Vermorel, unpublished results) had shown that $\mathrm{O}_{2}$ consumption of non-catheterized ewes remained unchanged over the whole underfeeding period, when expressed on a MW basis. Consequently, $\mathrm{O}_{2}$ consumption of catheterized ewes during the first weeks of underfeeding was predicted from $\mathrm{O}_{2}$ consumption measured in the last week of undernutrition (expressed per unit MW) and weekly averaged LW. Measured (weeks $-1,+6 /+7$ ) and predicted $($ weeks +1 to +5$)$ results are shown in Table 3. No correction has been applied for variable spontaneous physical activity. Standing time averaged 847 (SE 125.0) and 432 (SE 33.4) $\mathrm{min} / \mathrm{d}$ in weeks -1 and $+6 /+7$ respectively.

\section{Contributions of tissues to whole-animal energy metabolism}

The effects of underfeeding on the estimated contributions are shown in Table 3. PDV contributed $30.9 \%$ to total $\mathrm{O}_{2}$ consumption at maintenance and $26.8 \%$ on average at half maintenance. The contribution tended to be slightly lower in week +1 than in subsequent weeks, however, none of these effects were significant. As far as the liver was concerned, its contribution to total $\mathrm{O}_{2}$ consumption showed a non-significant decrease from $25.5 \%$ at maintenance to $20.5 \%$ at half maintenance (weeks +3 to +5 ). Erratic results were calculated for week +1 ; they were due to one animal that presented high hepatic blood flows in that week. The contribution calculated without that animal averaged $22.3 \%$ in week +1 . Finally, contribution of hindquarters to total $\mathrm{O}_{2}$ consumption increased 
Table 3. Weekly averages of live weights $(\mathrm{kg})$, measured (weeks $-1,+6$ or +7 ) and estimated (weeks +1 to +5 ) whole-animal oxygen consumption (litres/d) and contribution of tissues to this variable $(\%)$ during maintenance $($ week -1$)$ and half-maintenance $($ weeks +1 to +5$)$ feeding periods in ewes*

(Mean values with standard errors of treatment means)

\begin{tabular}{|c|c|c|c|c|c|c|c|c|c|c|}
\hline Week ... & -1 & +1 & +2 & +3 & +4 & +5 & $\begin{array}{r}+6 \\
\text { and } \\
+7\end{array}$ & SEM & H-F Eps & $\begin{array}{c}\text { Effect of } \\
\text { underfeeding }\end{array}$ \\
\hline $\begin{array}{l}\text { Live weight } \\
\mathrm{O}_{2} \text { consumption, } \\
\text { whole animal } \uparrow\end{array}$ & $\begin{array}{l}48 \cdot 6 \\
324\end{array}$ & $\begin{array}{l}46 \cdot 1 \\
242\end{array}$ & $\begin{array}{l}44 \cdot 9 \\
237\end{array}$ & $\begin{array}{l}43 \cdot 5 \\
232\end{array}$ & $\begin{array}{l}43 \cdot 2 \\
230\end{array}$ & $\begin{array}{l}42 \cdot 1 \\
226\end{array}$ & $\begin{array}{c}40 \cdot 9 \\
221\end{array}$ & $\begin{array}{c}0.21 \\
-\end{array}$ & $\underline{0.73}$ & $\begin{array}{c}P<0.001 \\
-\end{array}$ \\
\hline $\begin{array}{l}\text { Contribution of tissues } \\
\text { PDV } \\
\text { Liver } \\
\text { Hindquarters }\end{array}$ & $\begin{array}{l}30 \cdot 9 \\
25 \cdot 5 \\
13 \cdot 8\end{array}$ & $\begin{array}{l}25 \cdot 7 \\
27 \cdot 5 \\
16 \cdot 5\end{array}$ & $\begin{array}{l}27 \cdot 5 \\
18 \cdot 4 \\
19 \cdot 2\end{array}$ & $\begin{array}{l}26 \cdot 0 \\
20 \cdot 8 \\
18 \cdot 8\end{array}$ & $\begin{array}{l}27 \cdot 1 \\
20 \cdot 3 \\
17 \cdot 9\end{array}$ & $\begin{array}{l}27 \cdot 5 \\
22.6 \\
19 \cdot 0\end{array}$ & - & $\begin{array}{l}1.64 \\
2.53 \\
0.97\end{array}$ & $\begin{array}{l}0.46 \\
0.56 \\
0.57\end{array}$ & $\begin{array}{c}\text { NS } \\
\text { NS } \\
P<0.02\end{array}$ \\
\hline
\end{tabular}

H-F Eps, Huynh \& Feldt epsilon adjustment; NS, not significant; PDV, portal-drained viscera.

* For details of diets and procedures, see pp. 210-213.

$\dagger$ Whole animal results reported for weeks +1 to +5 were estimated as described on p. 217 .

$(P<0.02)$ from $13.8 \%$ at maintenance to an average of $18.3 \%$ at half maintenance. An intermediate contribution was calculated for week +1 , but no significant changes were noted between weeks +1 to +5 of undernutrition.

\section{Body composition}

At the end of the underfeeding period, digestive contents represented $16.3 \% \mathrm{LW}$. Emptybody weight was composed of $5 \cdot 7 \%$ blood, $11 \cdot 0 \%$ PDV, $1 \cdot 3 \%$ liver and $70.4 \%$ carcass. The PDV contained a larger proportion of total abdominal fat $(53 \%)$ than of other tissues trimmed of abdominal fat $(47 \%)$. The carcass itself was divided into hindquarters $(31.7 \%$ empty-body weight) and forequarters (68.3\%). The former contained $59.8 \%$ meat, $27.3 \%$ bones and $12.9 \%$ skin, whereas the latter contained slightly less meat $(51.3 \%)$ but more bones $(35.0 \%)$, and a similar proportion of skin $(13.7 \%)$.

The average DM contents of adipose-tissue-free PDV, abdominal fat, liver, meat hindquarters, meat forequarters and skin were $0.203,0.832,0.287,0.334,0.344$ and $0.262 \mathrm{~g} \mathrm{DM} / \mathrm{kg}$. The average $\mathrm{N}$ contents were 105 , non-estimated, $104,98,76$ and $140 \mathrm{mg} \mathrm{N} / \mathrm{g} \mathrm{DM}$ in the same respective order. Finally the average energy contents were $27 \cdot 2,39 \cdot 5,24 \cdot 4,28 \cdot 0,30 \cdot 5$ and $24 \cdot 1 \mathrm{~kJ} / \mathrm{g}$ DM respectively.

\section{Tissue metabolic rates}

$\mathrm{O}_{2}$ consumption by tissues at the end of the underfeeding period was expressed per unit weight or per unit $\mathrm{N}$ content of tissues (Table 4). Metabolic rate of PDV was calculated in two other ways: on the basis of whole-tissue weight and on the basis of the adipose-tissuefree weight, as it is known that adipose tissues have a low metabolic rate (Baldwin et al. 1980). Similarly, metabolic rate of hindquarters was expressed on a whole-weight basis as well as on a boneless-weight basis. Little is known about the metabolic rate of bone; however, the contribution of protein synthesis in bone marrow to whole-leg protein synthesis is small (Baracos et al. 1991). A similar trend was assumed here for $\mathrm{O}_{2}$ consumption in hindquarters. 
Table 4. In vivo oxygen consumption by the portal-drained viscera (PDV), liver and hindquarters of ewes fed for 7 weeks at half-maintenance energy requirement, expressed per unit fresh weight ( $\mathrm{mmol} \mathrm{O}_{2} / d$ per $\mathrm{g}$ fresh weight) and per unit tissue nitrogen (mmol $\mathrm{O}_{2} / d$ $\operatorname{per} g N)^{*}$

(Mean values with their standard errors)

\begin{tabular}{|c|c|c|c|c|}
\hline & \multicolumn{2}{|c|}{ Fresh-weight basis } & \multicolumn{2}{|c|}{$\mathbf{N}$ basis } \\
\hline & Mean & SE & Mean & $\mathrm{SE}$ \\
\hline \multicolumn{5}{|l|}{ PDV } \\
\hline Whole & 0.81 & $0-116$ & - & - \\
\hline Adipose-tissue-free & 1.65 & 0.179 & 78.08 & 8.920 \\
\hline Liver & 4.89 & 0.391 & $164 \cdot 27$ & 14.895 \\
\hline \multicolumn{5}{|l|}{ Hindquarters } \\
\hline Whole & 0.27 & 0.015 & - & - \\
\hline Boneless & 0.38 & 0.028 & 11.86 & 1.091 \\
\hline
\end{tabular}

* For details of diet and procedures, see pp. 210-212.

On a fresh-weight basis, $\mathrm{O}_{2}$ consumption was lowest in boneless hindquarters and averaged $0.381 \mathrm{mmol} / \mathrm{d}$ per $\mathrm{g}$. It was 4.3 and 12.8 times higher in adipose-tissue-free PDV and liver respectively (Table 4). These proportions were slightly higher when $\mathrm{O}_{2}$ consumption was expressed per unit N:6.6 and 13.9 in the same respective order. It should also be pointed out that $\mathrm{O}_{2}$ consumption of PDV expressed on an adipose-tissue-free basis was twice that expressed on a whole-tissue basis.

\section{DISCUSSION}

Effects of underfeeding on oxygen consumption by splanchnic tissues

As expected from the literature, underfeeding induced lower $\mathrm{O}_{2}$ consumption rates by the PDV $(-34 \%)$ and the liver $(-38 \%)$. The responses of each tissue bed were proportionally similar as also indicated by Reynolds et al. (1992). In the fed state the liver has tended to be proportionally more responsive than the PDV (Burrin et al. 1989; Reynolds et al. 1991). The opposite has been noted in the fasted state (Lomax \& Baird, 1983; Eisemann \& Nienaber, 1990; Huntington et al. 1990). This could suggest that, following changes in feeding level, the response of the PDV might primarily be controlled by the amount of absorbed nutrients whereas that of the liver would also depend on the balance among available nutrients, which determines the orientation of the metabolic pathways in the liver. Indeed, in the fasted state the liver would need to maintain a high activity rate in particular for gluco-, urea- and ketogenesis. Underfeeding at $50 \%$ below maintenance probably creates a situation which is intermediate between the fed and the fasted states.

These reductions in the $\mathrm{O}_{2}$ requirements of splanchnic tissues were detected from variations in both $\mathrm{O}_{2}$ supply and $\mathrm{O}_{2}$ extraction rates.

Blood flows were particularly concerned as major determinants of $\mathrm{O}_{2}$ supply and underfeeding greatly reduced portal and hepatic venous blood flows. The influence of level of feeding on splanchnic (especially portal) blood flows is widely documented (see Ortigues, 1991, for review). Linear or curvilinear relationships have been established but reports vary as to the quantitative changes observed. The relative importance of the responses noted at the portal and hepatic venous levels varies between reports, probably because of 
methodological difficulties. In particular, the role of the hepatic artery in the long-term regulation of total hepatic blood flow needs elucidating.

Changes in $\mathrm{O}_{2}$ consumption of the PDV had been closely related to changes in blood flows (Lindsay, 1993). In contrast, an important aspect of the present results was the demonstration that the total oxidative activity of the splanchnic tissues dropped with underfeeding to a greater extent than $\mathrm{O}_{2}$ supply did. Consequently, the $\mathrm{O}_{2}$ extraction rates decreased in the PDV (significantly) as well as in the liver (non-significantly), showing similar trends as in previously published reports. Indeed, literature results concerning the PDV most often showed no changes (Burrin et al. 1989; Eisemann \& Nienaber, 1990; Reynolds et al. 1991, 1992) or even some decreases (Huntington et al. 1990) in extraction rates with reduced intakes. Non-significant increases have been noted only once (Reynolds et al. 1991). In the liver, two different situations were identified. In the fed state, $\mathrm{O}_{2}$ extraction also varied in the same direction as intake (Burrin et al. 1989; Reynolds et al. 1991, 1992). A compensatory mechanism took place only in the very specific situation of fasting; the hepatic $\mathrm{O}_{2}$ extraction rate was then more elevated than in the fed state (Eisemann \& Nienaber, 1990; Huntington et al. 1990).

From this broad picture it appears that when different levels of feed allowances are applied above fasting, the oxidative requirements of splanchnic tissues seem to vary to a greater extent than blood flows. Since nutrient supply to tissues also changes partly with blood flow, this mechanism could be interpreted as a buffering role of the splanchnic tissues which lowered the nutritional challenge imposed on peripheral tissues by the $50 \%$ reduction in energy intake. Indeed, $\mathrm{O}_{2}$ fluxes leaving the liver and entering the general circulation were only reduced by $11 \%$.

\section{Effects of underfeeding on oxygen consumption by hindquarters}

The hindquarters was the only tissue bed among those measured which maintained a relatively stable $\mathrm{O}_{2}$ uptake whatever the feeding level, succeeding in compensating for the small drop in $\mathrm{O}_{2}$ supply by a tendency for a greater $\mathrm{O}_{2}$ extraction rate. Similarly, $\mathrm{O}_{2}$ consumption of hindlimbs has generally been unaffected (Bell \& Thompson, 1979; Bird et al. 1981; Symonds \& Lomax, 1990) by intake; an increase has been noted by Eisemann \& Nienaber (1990) only.

The drop in $\mathrm{O}_{2}$ supply to the hindquarters at half maintenance could be linked to a small $(-11 \%)$ but significant decrease in aortal blood flow. In the literature the effects of feeding level on muscle blood flow have been contradictory even though increasing evidence supports significant and parallel changes. No changes were noted by Bell \& Thompson (1979), Bird et al. (1981), Teleni et al. (1986) and Symonds \& Lomax (1990), whereas decreases in hind-limb or muscle blood flows were measured with reduced intake by Oddy et al. (1984), Gregory \& Christopherson (1986), Heitmann et al. (1986), Early et al. (1987), Eisemann \& Nienaber (1990) and Harris et al. (1992). Still, muscle blood flows appear to be much more influenced by physical activity than by nutritional factors (Bird et al. 1981; Pethick et al. 1987; Harris et al. 1992). Consequently the lack of careful monitoring of physical activity during measurements might strongly influence conclusions inasmuch as the effect of feeding level appears to be much lower than that of posture. In the present experiment, overlooking the influence of physical activity would have resulted in a slight underestimation of the drop in blood flow with undernutrition $(-7 \%$ instead of $-11 \%)$ and an overestimation of the residual error associated with the measurement.

The increase in $\mathrm{O}_{2}$ extraction rate by the hindquarters measured with underfeeding was small but significant. No such changes have been reported by other authors. Fasting caused either no changes (Jarrett et al. 1976; Teleni et al. 1986) or an increase (Eisemann \& Nienaber, 1990) in $\mathrm{O}_{2}$ extraction rates. 
Consequently, the notable point of the present results is that hindquarters have shown a remarkable stability in their $\mathrm{O}_{2}$ requirements with intake. They also showed their ability to adapt their $\mathrm{O}_{2}$ extraction capacity, even if the challenge imposed on muscles was limited since $\mathrm{O}_{2}$ supply did not change drastically.

\section{Effects of the duration of underfeeding on oxygen consumption by tissues}

In terms of $\mathrm{O}_{2}$ consumption, the response of splanchnic tissues to underfeeding occurred very rapidly: within $5 \mathrm{~d}$ in the PDV and within 5 to $10 \mathrm{~d}$ in the liver. It is remarkable that no further changes were noted during the 5 or 6 following weeks of underfeeding. Data on the response time of $\mathrm{O}_{2}$ consumption to changes in intake are scarce. Unclear results were obtained by Burrin et al. (1989) because of some confounding between the effect of time and the effect of feeding level.

The rapidity of response noted here probably originated from digestion processes. The mean retention time of hay-based diets in the gastrointestinal tract of sheep is approximately $2 \mathrm{~d}$ (Warner, 1981). In addition, stabilization of rumen fermentations estimated on the basis of $\mathrm{CH}_{4}$ production seemed to take only 3 to $4 \mathrm{~d}$ after the drop in the plane of feeding (I. Ortigues and M. Vermorel, unpublished results) or 9 to $10 \mathrm{~d}$ when fasted sheep were refed (Blaxter \& Graham, 1955). Consequently, in the present experiment, production of digestion end-products must have been already substantially lowered $5 \mathrm{~d}$ after the drop in the plane of feeding, leading to reduced splanchnic blood flows (Lanciault \& Jacobson, 1976). Indeed, the availability of nutrients (volatile fatty acids and $\mathrm{CO}_{2}$ in particular) in the rumen of fed sheep seemed to determine portal or ruminal blood flows (Sellers, 1965; Weekes \& Webster, 1975), even though recent data obtained on ruminants fed only by intragastric infusions modulated this conclusion (Gross et al. 1990). Subsequently, any further changes in the digestion processes would be of too low a magnitude to be detected in terms of blood flows and $\mathrm{O}_{2}$ consumption.

A slight question remains as to the speed of response at the hepatic level since intermediate but non-significantly different values were noted on day 5 for hepatic $\mathrm{O}_{2}$ consumption and blood flow.

The rapidly reduced $\mathrm{O}_{2}$ consumption of splanchnic tissues following a restriction in nutrient availability can also be associated with the rate at which splanchnic tissues adapt their mass. In lambs (Rompala \& Hoagland, 1987; Burrin et al. 1990), changes in splanchnic tissue weight seemed to occur very rapidly, i.e. within 5 to $7 \mathrm{~d}$. In steers, changes in liver mass occurred after $3 \mathrm{~d}$ only (Richmond et al. 1988). They were probably related to the very high protein turnover rate of splanchnic tissues and the control of both protein synthesis and degradation rates by energy intake (Lobley et al. 1992, 1994). In adults, evidence for changes in the mass of splanchnic tissues with feeding level is controversial (Ortigues, 1991) and is associated with lower protein fractional synthesis rates than in the young (Lobley, 1993). Direct comparison between the rates of change in tissue mass and in aerobic demand would be necessary to determine the adaptation potential of splanchnic tissues.

For hindquarters the time trend of response was difficult to appreciate precisely from the present results. The slight decrease in blood flow with underfeeding also occurred very rapidly (within $5 \mathrm{~d}$ ). Limited published evidence would suggest that this change was of neuro-hormonal origin (Greenway, 1983; Koch et al. 1991) rather than due to reduced nutrient availability (Pethick \& Vernau, 1984). No changes in $\mathrm{O}_{2}$ consumption were noted with the duration of underfeeding. Any eventual changes in hindquarters energy requirements might then take place over a much longer term than that studied in the present experiment. Indeed, muscle protein synthesis, ion transport and substrate cycles 
can respond to intake (Lobley, 1990; Lobley et al. 1992). It has also been suggested that modifications occur in the ratio of slow to fast twitch muscle fibre types in total muscle mass with energy restriction (Henriksson, 1992).

In conclusion, no progressive adaptation of tissue $\mathrm{O}_{2}$ consumption was noted within the 7 weeks of the experiment, contrary to what had been suggested by Shetty (1990). Changes either took place very rapidly ( $5 \mathrm{~d}$ ) at the splanchnic level in agreement with digestion processes, or might take place on a much longer time scale ( $>7$ weeks) at the hindquarters level.

\section{Contribution of tissues to whole-animal response with underfeeding}

Some general comments are first necessary on the overall levels of the contributions of the different tissue beds to total $\mathrm{O}_{2}$ consumption. The measured contributions reported here for the PDV and the liver are among the highest contributions which are generally attributed to ruminants in a high production state or at high intake levels (Huntington \& McBride, 1988). This is probably related to the fact that splanchnic blood flows (48 and $54 \mathrm{ml} / \mathrm{min}$ per $\mathrm{kg} \mathrm{LW}$ at the portal and hepatic venous levels respectively) were generally in the higher range of those noted by Bergman \& Wolff (1971), Pethick et al. (1981) and Heitmann et al. (1986) in mature sheep or ewes, and by Burrin et al. (1989) and Gross et al. (1990) in growing lambs (34-46 and 38-51 $\mathrm{ml} / \mathrm{min}$ per $\mathrm{kg} \mathrm{LW}$ in the same respective order) using a downstream PAH dilution technique. Additionally, the contributions carry an approximation related to the fact that whole-animal results were not standardized to a given posture while measurements of tissue energy metabolism were carried out while animals were standing. Correcting the whole-animal data using the measured time spent standing and the energy cost of standing calculated by us (I. Ortigues and M. Vermorel, unpublished results; 13.4 and $35.0 \mathrm{~J} / \mathrm{kg} \mathrm{LW}$ per min at maintenance and half maintenance respectively) would lower the contributions of the PDV, liver and hindquarters to $27 \cdot 6,24 \cdot 1$ and $13.6 \%$ at maintenance and $20.4,16.4$ and $14.3 \%$ at half maintenance respectively. These figures stress the importance of accounting for physical activity when measuring the contribution of tissues to whole-animal energy expenditure. Nevertheless, no correction was systematically applied here awaiting confirmation for such large differences in the energy cost of standing between feeding levels (I. Ortigues and M. Vermorel, unpublished results). These limitations show that some caution should be exercised when interpreting the absolute changes in whole-animal energy expenditure in relation to individual tissues. Still, the relative importance of each tissue should not be altered.

Changes in whole-animal heat production with level of feeding can be related to the energy metabolism of individual body tissues. In the present experiment, differences in total $\mathrm{O}_{2}$ consumption between week -1 and week $+5(98$ litres $/$ d) originated 39 and $32 \%$ from PDV (38 litres/d) and liver (31 litres/d) respectively. These results confirm the predominant role of splanchnic tissues in the changes of whole-animal energy expenditure with intake. In steers fed on lucerne (Medicago sativa) or orchard-grass silages, PDV contributed for 28 and $46 \%$ respectively to the increment in whole-animal $\mathrm{O}_{2}$ consumption with intake (Huntington et al. 1988). With $750 \mathrm{~g} / \mathrm{kg}$ concentrate diets, splanchnic tissues accounted for $35 \%$ (steers, Reynolds et al. 1992) or $44 \%$ (heifers, Reynolds et al. 1991) of total heat increment with intake. The higher proportions obtained in this paper might be due to the fact that a dry forage rather than a silage or concentrate diet was used.

By contrast, carcass accounted only for an additional $5 \%(5$ litres $/ \mathrm{d})$ of the difference. Symonds \& Lomax (1990) also found that muscles contributed only $6.8 \%$ to the drop in whole-body heat production with underfeeding. It was further calculated that differences in the cost of eating accounted for 6-9\% (5.6-8.8 litres $\left.\mathrm{O}_{2}\right)$ of the increment in $\mathrm{O}_{2}$ consumption, assuming that the energy cost of eating amounted to $5-8 \mathrm{~J} / \mathrm{g}$ fresh matter per 
$\mathrm{kg} \mathrm{LW}$ (Young, 1966) and assuming 20.46 J heat produced per litre $\mathrm{O}_{2}$ consumed (McLean, 1986).

These changes resulted in decreased contributions of splanchnic tissues to total $\mathrm{O}_{2}$ consumption with feeding level, in agreement with studies by other authors using forage diets (Burrin et al. 1989; Eisemann \& Nienaber, 1990; Reynolds et al. 1991), even though our results eluded statistical significance. In contrast, the contribution of hindquarters to whole-body $\mathrm{O}_{2}$ consumption was found to increase with underfeeding, similarly to Symonds \& Lomax (1990) but contrarily to Harris et al. (1989) and Eisemann \& Nienaber (1990). As discussed previously, changes in physical activity may be sufficient to mask any nutritional changes.

Unfortunately, the present results do not allow the clear relation of the changes noted at tissue level with the progressive adaptation in whole-animal energy metabolism (I. Ortigues and $M$. Vermorel, unpublished results). Contributions of the three tissue beds to total $\mathrm{O}_{2}$ consumption tended to increase with the duration of underfeeding reflecting the facts that $\mathrm{O}_{2}$ consumption of splanchnic tissues responded to underfeeding within the first week and that $\mathrm{O}_{2}$ consumption of the hindquarters remained unchanged while that of the whole animal decreased more progressively with time. Nevertheless total $\mathrm{O}_{2}$ consumption was assumed here to decrease at the same rate as MW whereas $L W$ loss $(-116 \mathrm{~g} / \mathrm{d})$ of the present catheterized ewes was greater $(P<0.05)$ than that of non-catheterized ewes $(-72 \mathrm{~g} / \mathrm{d})$ submitted to the same energy restriction (I. Ortigues and M. Vermorel, unpublished results). This difference could be due either to higher energy requirements of catheterized $v$. non-catheterized ewes (ME requirements for maintenance were calculated to be $14 \%$ higher in catheterized than in intact animals), or to a more severe degree of undernutrition applied to catheterized animals because of repeated blood sampling. It was estimated that blood sampling over $1 \mathrm{~d}$ would remove $1200 \mathrm{~kJ}$ net energy (using an energy content of blood of $4200 \mathrm{~kJ} /$ litre, calculated from Schulz et al. (1974)), i.e. $2400 \mathrm{~kJ} \mathrm{ME}$, assuming an efficiency of energy utilization for protein deposition of 0.5 (Institut National de la Recherche Agronomique, 1978). Since blood proteins would be reconstituted progressively with time, this would correspond over $7 \mathrm{~d}$ periods to a reduction of $5.6 \%$ in daily ME allowances in the maintenance period and of $11.7 \%$ in the half-maintenance period. Consequences of blood sampling on the degree of underfeeding are difficult to quantify but probably altered the magnitude of the whole-animal response with time.

\section{Tissue metabolic rates}

Adaptation of tissue metabolic rates to underfeeding could have been more closely appreciated through changes in the amounts of $\mathrm{O}_{2}$ consumed per unit time and per unit tissue weight. Burrin et al. (1990) suggested that changes in PDV or even in liver total $\mathrm{O}_{2}$ consumption with intake resulted primarily from changes in tissue weights rather than from changes in tissue metabolic rates. The opposite might be true for the hindlimbs (Harris et al. 1989). The major limitation of the present data is the absence of body composition measurements at maintenance and during the first weeks of underfeeding.

A general comment can still be made. It is likely that the basis used to express tissue metabolic rates can have some influence when calculating tissue $\mathrm{O}_{2}$ consumption from metabolic rates and tissue weights. For example, total carcass $\mathrm{O}_{2}$ consumption was extrapolated from dissection data and metabolic rate of boneless hindquarters on the basis of wet tissue weight and amounted to $60.3 \%$ of total $\mathrm{O}_{2}$ consumption. Consequently, the total of PDV, liver and carcass explained $110.5 \%$ of whole animal $\mathrm{O}_{2}$ consumption. However, forequarters were fatter than hindquarters, and adipose tissues are known to have a low metabolic rate (Baldwin et al. 1980). Therefore, if the extrapolation was carried out on the basis of the $\mathbf{N}$ content of meat and skin, contribution of the carcass would be 
reduced to $55.6 \%$. The sum of PDV, liver and carcass would then explain $105.8 \%$ of wholeanimal $\mathrm{O}_{2}$ consumption.

\section{Conclusions and perspectives}

Splanchnic and hindquarters tissues responded very differently to a $50 \%$ reduction in intake. First, they were imposed different challenges since reduction in $\mathrm{O}_{2}$ supply was greater in splanchnic tissues $(-18$ to $-21 \%)$ than in hindquarters $(-12 \%)$. Second, only splanchnic tissues reacted by drastically lowering their total energy expenditure $(-34$ to $-38 \%$ ). They were even able to reduce their $\mathrm{O}_{2}$ extraction rates. These concurrent and extremely rapid (within $5 \mathrm{~d}$ ) mechanisms allowed great attenuation of the changes in energy supply to hindquarters, which itself was able to modulate its $\mathrm{O}_{2}$ extraction rate in order to meet its energy requirements. Substantial adaptation of muscle metabolism to undernutrition probably occurs in a longer time-scale than that studied.

This repartitioning of the energy among body tissues might be the result of a reduced metabolic activity of splanchnic tissues (lower nutrient absorption and lower metabolic transformations of nutrients at the hepatic level). Alternatively, repartitioning might partly be under neuro-hormonal control. Indeed, a determining component of energy supply to tissues is blood flow which is itself under both nutritional and neuro-hormonal regulation (Lanciault \& Jacobson, 1976; Granger et al. 1980; Koch et al. 1991). The sympathetic nervous system might be particularly involved since it modulates gastrointestinal and muscle blood flows (Greenway, 1983), and its activity is known to decrease with underfeeding (Shetty, 1990). The relevance of these two hypotheses needs to be examined.

The authors express their appreciation to J. Lefaivre for surgery, R. Souchet and C. Léoty for taking care of the animals, to A. Isserty and F. Duboisset for chemical and data analysis, to J. C. Massabuau (CNRS, Arcachon) for his advice on blood gas analyses, to J. Vernet and B. Carlier for indirect calorimetry measurements, to $\mathbf{M}$. Houzel and $\mathbf{M}$. Bruchet for their help during sampling, to $\mathbf{M}$. Mailhot for statistical advice and to M. Vermorel for helpful discussions on the protocol and results.

\section{REFERENCES}

Baldwin, R. L., Smith, N. E., Taylor, J. \& Sharp, M. (1980). Manipulating metabolic parameters to improve growth rate and milk secretion. Journal of Animal Science 51, 1416-1428.

Baracos, V. E., Brun-Bellut, J. \& Marie, M. (1991). Tissue protein synthesis in lactating and dry goats. British Journal of Nutrition 66, 451-465.

Bell, A. W. \& Thompson, G. E. (1979). Free fatty acid oxidation in bovine muscle in vivo: effects of cold exposure and feeding. American Journal of Physiology 237, E309-E315.

Bergman, E. N. \& Wolff, J. E. (1971). Metabolism of volatile fatty acids by liver and portal-drained viscera in sheep. American Journal of Physiology 221, 586-592.

Bird, A. R., Chandler, K. D. \& Bell, A. W. (1981). Effects of exercise and plane of nutrition on nutrient utilization by the hind limb of the sheep. Australian Journal of Biological Science 34, 541-550.

Blaxter, K. L. \& Graham, N. McC. (1955). Plane of nutrition and starch equivalents. Journal of Agricultural Science, Cambridge 46, 292-306.

Burrin, D. G., Ferrell, C. L., Britton, R. A. \& Bauer, M. (1990). Level of nutrition and visceral organ size and metabolic activity in sheep. British Journal of Nutrition 64, 439-448.

Burrin, D. G., Ferrell, C. L., Eisemann, J. H., Britton, R. A. \& Nienaber, J. A. (1989). Effect of level of nutrition on splanchnic blood flow and oxygen consumption in sheep. British Journal of Nutrition 62, $23-34$.

Clapperton, J. L. \& Blaxter, K. L. (1965). Absence of long-term adaptation in the energy metabolism of sheep on constant-feed. Proceedings of the Nutrition Society 24, 33-34.

Early, R. J., Thompson, J. R., Christopherson, R. J. \& Sedgwick, G. W. (1987). Blood branched-chain amino and alpha-keto acid concentrations and net exchange across the portal-drained viscera and hindlimb of fed and fasted ruminants. Canadian Journal of Animal Science 67, 1011-1020.

Eisemann, J. H. \& Nienaber, J. A. (1990). Tissue and whole-body oxygen uptake in fed and fasted steers. British Journal of Nutrition 64, 399411.

Granger, D. N., Richardson, P. D. I., Kvietys, P. R. \& Mortillaro, N. A. (1980). Intestinal blood flow. Gastroenterology 78, 837-863. 
Greenway, C. V. (1983). Role of splanchnic venous system in overall cardiovascular homeostasis. Federation Proceedings 42, 1678-1684.

Gregory, N. G. \& Christopherson, R. J. (1986). Effect of fasting on capillary blood flow in sheep. Research in Veterinary Science 40, 357-360.

Gross, K. L., Harmon, D. L. \& Avery, T. B. (1990). Portal-drained visceral fiux of nutrients in lamb fed alfalfa or maintained by total intragastric infusion. Journal of Animal Science 68, 214-221.

Harris, P. M., Garlick, P. J. \& Lobley, G. E. (1989). Interactions between energy and protein metabolism in the whole body and hindlimb of sheep in response to intake. In Energy Metabolism of Farm Animals, pp. 167-170 [Y. van der Honing and W. H. Close, editors]. Wageningen: Pudoc.

Harris, P. M., Skene, P. A., Buchan, V., Milne, E., Calder, A. G., Anderson, S. E., Connell, A. \& Lobley, G. E. (1992). Effect of food intake on hind-limb and whole-body protein metabolism in young growing sheep: chronic studies based on arterio-venous techniques. British Journal of Nutrition 68, 389-407.

Heitmann, R. N., Sensenig, S. C., Reynolds, C. K., Fernandez, J. M. \& Dawes, D. J. (1986). Changes in energy metabolite and regulatory hormone concentrations and net fluxes across splanchnic and peripheral tissues in fed and progressively fasted ewes. Journal of Nutrition 116, 2516-2524.

Henriksson, J. (1992). Energy metabolism in muscle: its possible role in the adaptation to energy deficiency. In Energy Metabolism: Tissue Determinants and Cellular Corollaries, pp. 345-365 [J. M. Kinney and H. N. Tucker, editors]. New York: Raven Press.

Homer, J. H. (1989). Introduction to Experimental Design in Psychology. New York: Harper \& Row.

Huntington, G. B. (1982). Portal blood flow and net absorption of ammonia-nitrogen, urea-nitrogen, and glucose in nonlactating Holstein cows. Journal of Dairy Science 65, 1155-1162.

Huntington, G. B. (1990). Energy metabolism in the digestive tract and liver of cattle: influence of physiological state and nutrition. Reproduction Nutrition Development 30, 35-47.

Huntington, G. B., Eisemann, J. H. \& Whitt, J. M. (1990). Portal blood flow in beef steers: comparison of techniques and relation to hepatic blood flow, cardiac output and oxygen uptake. Journal of Animal Science 68, $1666-1673$.

Huntington, G. B. \& McBride, B. W. (1988). Ruminant splanchnic tissues: energy costs of absorption and metabolism. In Biomechanisms Regulating Growth and Development, pp. 313-327 [G. L. Steffens and T. S. Rumsey, editors]. Boston: Kluver Academic Publishers.

Huntington, G. B., Varga, G. A., Glenn, B. P. \& Waldo, D. R. (1988). Net absorption and oxygen consumption by Holstein steers fed alfalfa or orchardgrass silage at two equalized intakes. Journal of Animal Science 66 , 1292-1302.

Institut National de la Recherche Agronomique (1978). Alimentation des Ruminants. Versailles: INRA Publications.

Isserty, A. \& Ortigues, I. (1994). Méthodes d'exploitation de données concernant les débits sanguins mesurés au niveau des viscères et du train-arrière chez la brebis (Methods of analysis of splanchnic and aortic blood flow data obtained in ewes). Reproduction Nutrition Development 34, 399-413.

Jarrett, I. G., Filsell, O. H. \& Ballard, F. J. (1976). Utilization of oxidizable substrates by the sheep hind limb: effects of starvation and exercise. Metabolism 25, 523-531.

Katz, M. L. \& Bergman, E. N. (1969). Simultaneous measurements of hepatic and portal venous blood flow in the sheep and dog. American Journal of Physiology 216, 946-952.

Koch, L. G., Strick, D. M., Britton, S. L. \& Metting, P. J. (1991). Reflex versus autoregulatory control of hindlimb blood flow during treadmill exercise in dogs. American Journal of Physiology 260, H436-H444.

Lanciault, G. \& Jacobson, E. D. (1976). The gastrointestinal circulation. Gastroenterology 71, 851-873.

Lindsay, D. B. (1993). Metabolism of the portal drained viscera. In Quantitative Aspects of Ruminant Digestion and Metabolism, pp. 267-289 [J. M. Forbes and J. France, editors]. Wallingford: CAB International.

Lobley, G. E. (1990). Energy metabolism reactions in ruminant muscle: responses to age, nutrition and hormonal status. Reproduction Nutrition Development 30, 13-34.

Lobley, G. E. (1993). Species comparisons of tissue protein metabolism: effects of age and hormonal action. Journal of Nutrition 123, 337-343.

Lobley, G. E., Connell, A., Milne, E., Newman, A. M. \& Ewing, T. A. (1994). Protein synthesis in splanchnic tissues of sheep offered two levels of intake. British Journal of Nutrition 71, 3-13.

Lobley, G., Harris, P. M., Skene, P. A., Brown, D., Milne, E., Calder, A. G., Anderson, S. E., Garlick, P. J., Nevison, I. \& Connell, A. (1992). Responses in tissue protein synthesis to sub- and supra-maintenance intake in young growing sheep: comparison of large-dose and continuous-infusion techniques. British Journal of Nutrition 68, 373-388.

Lomax, M. A. \& Baird, G. D. (1983). Blood flow and nutrient exchange across the liver and gut of the dairy cow. Effects of lactation and fasting. British Journal of Nutrition 49, 481-496.

McLean, J. A. (1986). The significance of carbon dioxide and methane measurements in the estimation of heat production in cattle. British Journal of Nutrition 55, 631-633.

Oddy, V. H., Gooden, J. M. \& Annison, E. F. (1984). Partitioning of nutrients in Merino ewes. I. Contribution of skeletal muscle, the pregnant uterus and the lactating mammary gland to total energy expenditure. Australian Journal of Biological Science 37, 375-388.

Ortigues, I. (1991). Adaptation du métabolisme énergétique des ruminants à la sous-alimentation. Quantification 
au niveau de l'animal entier et de tissus corporels (Adaptation of energy metabolism to undernutrition in ruminants. Quantification in the whole animal and in individual body tissues.) Reproduction Nutrition Development 31, 593-616.

Ortigues, I., Durand, D. \& Lefaivre, J. (1994). Use of para amino hippuric acid to measure blood flows through portal drained viscera, liver and hindquarters in sheep. Journal of Agricultural Science, Cambridge 122, 299-308.

Pethick, D. W., Harman, N. \& Chong, J. K. (1987). Non-esterified long-chain fatty acid metabolism in fed sheep at rest and during exercise. Australian Journal of Biological Science 40, 221-234.

Pethick, D. W., Lindsay, D. B., Barker, P. J. \& Northrop, A. J. (1981). Acetate supply and utilization by the tissues of sheep in vivo. British Journal of Nutrition 46, 97-110.

Pethick, D. W. \& Vernau, B. (1984). The effect of acetate on the utilization of glucose by skeletal muscle on the sheep hindlimb. Canadian Journal of Animal Science 64, Suppl. 1, 291-292.

Reynolds, C. K., Lapierre, H., Tyrrell, H. F., Elsasser, T. H., Staples, R. C., Gaudreau, P. \& Brazeau, P. (1992). Effects of growth hormone-releasing factor and feed intake on energy metabolism in growing beef steers: net nutrient metabolism by portal-drained viscera and liver. Journal of Animal Science 70, 752-763.

Reynolds, C. K., Tyrrell, H. F. \& Reynolds, P. J. (1991). Effects of diet forage-to-concentrate ratio and intake on energy metabolism in growing beef heifers: whole body energy and nitrogen balance and visceral heat production. Journal of Nutrition 121, 994-1003.

Richmond, C. E., Lunt, D. K., Greene, L. W. \& Byers, F. M. (1988). Effects of dietary restriction and subsequent re-alimentation on liver mass in growing/finishing beef steers. Nutrition Reports International 38, 501-507.

Rompala, R. E. \& Hoagland, T. A. (1987). Effect of level of alimentation on visceral organ mass and the morphology and $\mathrm{Na}^{+}, \mathrm{K}^{+}$adenosinetriphosphatase activity of intestinal mucosa in lambs. Journal of Animal Science 65, 1058-1063.

Schultz, E., Oslage, H. J. \& Daenicke, R. (1974). Untersuchung über die Zuzammensetzung der Korpersubstanz sowie den Stoff- und Energieansatz bei Wachsenden Mastbullen (Research work on body composition, and energy and nitrogen utilization in bulls). Zeitschrift für Tierphysiologie, Tierernährung und Futtermittlekunde Suppl. 4, 1-70.

Sellers, A. F. (1965). Blood flow in the rumen vessels. In Physiology of Digestion in the Ruminant, pp. 171-184 [R. W. Dougherty, editor]. Washington: Butterworths.

Shetty, P. S. (1990). Physiological mechanisms in the adaptive response of metabolic rates to energy restriction. Nutrition Research Reviews 3, 49-74.

Statistical Analysis Systems (1987). SAS/STAT Guide for Personal Computers. Cary, NC: SAS Inst. Inc.

Symonds, M. E. \& Lomax, M. A. (1990). Effect of chronic cold exposure and underfeeding on hind-limb tissue metabolism in pregnant sheep. Journal of Agricultural Science, Cambridge 115, 421-428.

Teleni, E., Annison, E. F. \& Lindsay, D. B. (1986). Metabolism of valine and the exchange of amino acids across the hind-limb muscles of fed and starved sheep. Australian Journal of Biological Science 39, 379-393.

Tucker, V. A. (1967). Method for oxygen content and dissociation curves on microliter blood samples. Journal of Applied Physiology 23, 410-414.

Underwood, E. J. (1981). The Mineral Nutrition of Livestock. Slough : Commonwealth Agricultural Bureaux.

Vermorel, M., Bouvier, J.-C., Bonnet, Y. \& Fauconneau, G. (1973). Construction et fonctionnement de 2 chambres respiratoires du type "circuit-ouvert" pour jeunes bovins (Construction and operation of two "opencircuit" respiration chambers for young cattle). Annales de Biologie Animale, Biochimie et Biophysique 13, 659-681.

Wainman, F. W., Blaxter, K. L. \& Smith, J. S. (1972). The utilization of the energy of artificially dried grass prepared in different ways. Journal of Agricultural Science, Cambridge 78, 441-447.

Warner, A. C. I. (1981). Rate of passage of digesta through the gut of mammals and birds. Nutrition Abstracts and Reviews Series B 51, 789-820.

Weekes, T. E. C. \& Webster, A. J. F. (1975). Metabolism of propionate in the tissues of the sheep gut. British Journal of Nutrition 33, 425-438.

Young, B. A. (1966). Energy expenditure and respiratory activity of sheep during feeding. Australian Journal of Agricultural Research 17, 355-362. 